\title{
PHOSPHORUS TEST VALUES OF FRESH AND AIR-DRIED SOIL SAMPLES
}

\author{
Armi Kaila \\ University of Helsinki, Department of Agricultural Chemistry
}

Received November 2, 1962

It is often emphasized that drying of soil samples affects the solubility of soil phosphorus. Therefore, the use of fresh soil samples is recommended. Since this is not always possible, it would be necessary to know of what order the changes caused by air-drying may be. Yet, there is in the literature a relative dearth of analytical data concerning the effect of drying performed at lower temperatures: the term sair-drying» often means a treatment at $40^{\circ} \mathrm{C}$, or even at $60^{\circ} \mathrm{C}$ as in the paper by Hoffm ANN and Steinfatt (2).

In a previous work it was found (5) that in several cases, drying carried out at $40^{\circ} \mathrm{C}$ changed the phosphorus test values more than did drying at room temperature; sometimes the former treatment caused a decrease in the test value while an increase was found as the result of the latter treatment. In the present paper, some further results are reported of the comparison of data obtained for fresh soil samples and samples dried at about $20^{\circ} \mathrm{C}$. The methods used were the following: the acetic acid method (4), the somewhat modified method of BRAY and KURTZ (1) for the adsorbed P, and the method of TERÄSvUORI (6) in which the mexchangeable P", the corresponding $\mathrm{P}$ concentration in solution, and an indicator of the phosphate retention capacity of the soil are estimated.

\section{Material and methods}

The present material consists of 32 samples collected in September from different kinds of soils, including some garden soils and a few virgin soils.

The fresh samples were carefully mixed by hands, and six replicates were weighed for each determination. The rest of the samples were air-dried at room temperature, or at about $20^{\circ} \mathrm{C}$. When the same analyses were carried out on air- 
dry soil, the amount of soil dry matter was equal to that in the fresh sample, and distilled water was added in quantities corresponding to the original moisture content. These analyses were performed in four replicates.

The acetic acid solube $\mathrm{P}$ was determined by shaking $10 \mathrm{~g}$ samples of fresh soil, or the corresponding amounts of dry samples, for one hour in $100 \mathrm{ml}$ of 0.5 $\mathrm{N}$ acid.

The adsorbed $\mathrm{P}$ was extracted by shaking $10 \mathrm{~g}$ samples of fresh soil for one minute in $100 \mathrm{ml}$ of $0.03 \mathrm{~N} \mathrm{NH}_{4} \mathrm{~F}-0.025 \mathrm{~N} \mathrm{HCl}$.

The mexchangeable $\mathrm{P}_{\text {", }} \mathrm{x}_{\mathrm{o}}$, was determined by shaking $4 \mathrm{~g}$ of fresh soil in 200 $\mathrm{ml}$ of a solution which was $0.1 \mathrm{~N}$ with respect to both $\mathrm{KOH}$ and $\mathrm{K}_{2} \mathrm{CO}_{3}$ for two hours the first day and for 4 hours the second day.

Table 1. Soil samples

\begin{tabular}{|c|c|c|c|c|c|c|}
\hline $\begin{array}{c}\text { Number } \\
\text { of }\end{array}$ & Kind of soil & $\mathrm{pH}$ & C \% & $\mathrm{Fe} \%$ & Al \% & $\begin{array}{c}\text { Moisture } \\
\%\end{array}$ \\
\hline & Field soils & & & & & \\
\hline 1 & Sand & 5.7 & 5.0 & 0.42 & 0.39 & 26 \\
\hline 9 & - & 5.4 & 2.3 & 0.20 & 0.17 & 12 \\
\hline 17 & - & 5.8 & 1.6 & 0.22 & 0.23 & 9 \\
\hline 30 & Fine sand & 5.4 & 3.0 & 0.42 & 0.26 & 13 \\
\hline 8 & Loam & 6.7 & 5.3 & 0.40 & 0.26 & 24 \\
\hline 10 & , & 5.9 & 3.8 & 0.24 & 0.25 & 22 \\
\hline 12 & , & 6.1 & 2.5 & 0.24 & 0.20 & 20 \\
\hline 28 & Clay loam & 6.4 & 2.7 & 0.67 & 0.30 & 18 \\
\hline 29 & , & 5.1 & 2.7 & 0.51 & 0.29 & 17 \\
\hline 4 & Sandy clay & 5.7 & 4.7 & 0.47 & 0.38 & 25 \\
\hline 19 & , & 6.0 & 3.6 & 0.25 & 0.36 & 23 \\
\hline 11 & Silty clay & 5.2 & 7.7 & 0.62 & 0.87 & 40 \\
\hline 20 & , & 5.1 & 5.1 & 0.71 & 0.42 & 26 \\
\hline 24 & , & 5.1 & 4.2 & 0.56 & 0.35 & 17 \\
\hline 27 & Heavy clay & 5.1 & 5.0 & 0.40 & 0.30 & 15 \\
\hline 18 & Fen peat & 4.1 & 10.3 & 0.27 & 0.26 & 47 \\
\hline 15 & , & 4.2 & 33.2 & 1.03 & 0.68 & 72 \\
\hline \multirow[t]{2}{*}{16} & - subsoil & 4.8 & 31.2 & 0.64 & 0.70 & 82 \\
\hline & Garden soils & & & & & \\
\hline 6 & Sand & 5.0 & 2.3 & 0.13 & 0.18 & 15 \\
\hline 7 & , subsoil & 5.3 & 0.1 & 0.07 & 0.04 & 6 \\
\hline 14 & Sand & 6.5 & 8.0 & 0.20 & 0.26 & 32 \\
\hline 26 & , & 6.4 & 3.9 & 0.18 & 0.10 & 13 \\
\hline 22 & Fine sand & 7.0 & 3.9 & 0.33 & 0.21 & 13 \\
\hline 3 & Sandy clay & 6.8 & 4.4 & 0.56 & 0.33 & 29 \\
\hline 5 & - & 5.1 & 6.9 & 0.44 & 0.50 & 28 \\
\hline 21 & Heavy clay & 5.9 & 5.7 & 0.38 & 0.21 & 31 \\
\hline 23 & Clay + peat & 5.8 & 8.1 & 0.31 & 0.17 & 26 \\
\hline \multirow[t]{2}{*}{25} & , & 4.7 & 11.3 & 0.36 & 0.21 & 40 \\
\hline & Virgin soils & & & & & \\
\hline 13 & Sand & 4.8 & 8.5 & 0.29 & 0.42 & 44 \\
\hline 31 & Clay loam & 7.2 & 3.5 & 0.49 & 0.27 & 31 \\
\hline 32 & Silty clay & 7.2 & 1.1 & 0.44 & 0.20 & 23 \\
\hline 2 & Heavy clay & 5.2 & 8.2 & 1.16 & 0.74 & 42 \\
\hline
\end{tabular}


In order to be able to calculate the $\mathrm{P}$ concentration, $\mathrm{y}_{\mathrm{o}}$, in the solution, corresponding to the amount of mexchangeable P», TERÄsvuori (6) measures the $\mathrm{P}$ concentration in solutions of $0.0005 \mathrm{M} \mathrm{KH}_{2} \mathrm{PO}_{4}$ and $0.005 \mathrm{M} \mathrm{KH}_{2} \mathrm{PO}_{4}$ in equilibrium with $10 \mathrm{~g}$ of soil. In the present work the procedure was somewhat modified: instead of boiling the suspensions, they were heated on a boiling water-bath for two hours on two consecutive days. The Freundlich adsorption isotherm is em-

ployed for the calculation of $\mathrm{y}_{\mathrm{o}}$, and the coefficient $\alpha$ of the equation $\mathrm{x}=\alpha \cdot \mathrm{y}^{\mathrm{n}}$, is taken to indicate the phosphate retention capacity of the soil.

The soil samples are characterized by some data recorded in Table 1. The $\mathrm{pH}$-values refer to 1: 2.5 water suspension of dry samples, the organic C was determined by a somewhat modified method of WALKLEY (7), and the $\mathrm{Fe}$ and $\mathrm{Al}$ were extracted by TAMm's acid ammonium oxalate solution.

\section{Results}

The $\mathrm{P}$ test values of the fresh samples and the respective changes caused by drying at about $20^{\circ} \mathrm{C}$ are reported in Table 2 . The statistical significance of the differences between the data obtained for the fresh and air-dry samples were calculated according to the common Student's t-test. This method was not applicable to the computed values of $\mathrm{y}_{\mathrm{o}}$ and $a$, and since no other simple and reliable way was found, the statistical significance of the changes in these values was not controlled.

The amount of acetic acid solube $\mathrm{P}$ was not changed in 17 of the 32 samples. In two of the samples a slight increase is observable, and in 13 samples an average decrease of $4 \mathrm{ppm}$ or 13 per cent is found.

A more marked tendency to a decrease in the test values owing to air-drying is shown by the data for the $\mathrm{NH}_{4} \mathrm{~F}-\mathrm{HCl}$-solube $\mathrm{P}$. No change occurred in 11 of the 32 samples, and in two of the virgin soils the very low test value was doubled. But in 19 samples the decrease ranged from 1 to $72 \mathrm{ppm}$, or from 13 to 50 per cent, with the average decrease of 21 ppm or 28 per cent.

In the test values of TERÄSvUORI's method no change was found in about one half of the cases, and the other samples seem to be more evenly distributed into the groups of the increasing or decreasing values than they are in respect to the rapid tests. Air-drying caused a decrease in the value of $x_{0}$ in 10 samples, and an increase in 5 samples. The decreases ranged from 3 to $56 \mathrm{ppm}$ or from 5 to 23 per cent, with the average of $20 \mathrm{ppm}$ or 11 per cent. The increases ranged from 6 to $31 \mathrm{ppm}$, or from 12 to 19 per cent, with the average of $15 \mathrm{ppm}$ or 15 per cent.

Provided that the changes in the values of $\mathrm{y}_{0}$ and $\alpha$ are significant, an increase in $\mathrm{y}_{\mathrm{o}}$ may be found in 9 cases and a decrease in 7 cases, and an increase in $\alpha$ in 7 cases and a decrease in 10 cases.

Typical of the results is that only in relatively few cases the changes caused by air-drying in the various test values went in the same direction. Also all attempts failed to connect the effect of the air-drying with any of the soil characteristics studied. 
Table 2. P test values of fresh samples and changes caused by air-drying

\begin{tabular}{|c|c|c|c|c|c|c|c|c|c|c|}
\hline \multirow{2}{*}{$\begin{array}{l}\text { Number } \\
\text { of } \\
\text { sample }\end{array}$} & \multirow{2}{*}{\multicolumn{2}{|c|}{$\begin{array}{c}\text { Acetic acid P } \\
\text { ppm }\end{array}$}} & \multirow{2}{*}{\multicolumn{2}{|c|}{$\begin{array}{c}\mathrm{NH}_{4} \mathrm{~F}-\mathrm{HCl} P \\
\text { ppm }\end{array}$}} & \multicolumn{6}{|c|}{ Test values by Teräsvuori } \\
\hline & & & & & \multicolumn{2}{|c|}{$\begin{array}{c}\mathrm{x}_{o} \\
\mathrm{ppm}\end{array}$} & \multicolumn{2}{|c|}{$\begin{array}{r}\mathrm{y}_{o} \\
\mathrm{mg} / 1\end{array}$} & \multicolumn{2}{|c|}{$a$} \\
\hline \multicolumn{11}{|c|}{ Field soils } \\
\hline 1 & 18 & 0 & 38 & $-14 * * *$ & 192 & $+23 * * *$ & 1.2 & 0 & 176 & +29 \\
\hline 9 & 19 & $+1 * *$ & 65 & $-17 * * *$ & 179 & 0 & 1.6 & +0.6 & 159 & -19 \\
\hline 17 & 18 & 0 & 62 & $-14^{* * *}$ & 185 & 0 & 0.4 & -0.1 & 230 & -18 \\
\hline 30 & 102 & 0 & 147 & $-37 * * *$ & 713 & 0 & 9.9 & -0.2 & 471 & 0 \\
\hline 8 & 157 & $-15 * *$ & 106 & $-31 * * *$ & 463 & $-22 * *$ & 12.2 & -1.3 & 221 & 0 \\
\hline 10 & 13 & 0 & 22 & 0 & 120 & 0 & 1.3 & -0.2 & 109 & 0 \\
\hline 12 & 22 & $-2 * * *$ & 34 & $-11 * * *$ & 137 & $-13^{* * *}$ & 1.1 & +0.1 & 133 & -16 \\
\hline 28 & 19 & 0 & 6 & $-1^{* *}$ & 112 & 0 & 0.3 & 0 & 176 & 0 \\
\hline 29 & 20 & $-4^{* *}$ & 3 & 0 & 75 & $+9 * * *$ & 0.3 & 0 & 135 & +8 \\
\hline 4 & 10 & $-1 * *$ & 5 & 0 & 97 & $-9 * * *$ & 0.2 & 0 & 198 & -11 \\
\hline 19 & 74 & 0 & 16 & $-6^{* * *}$ & 166 & $-13^{* *}$ & 1.8 & +0.3 & 136 & 0 \\
\hline 11 & 8 & $-1 *$ & 21 & -1 & 299 & 0 & 0.2 & 0 & 465 & +15 \\
\hline 20 & 11 & 0 & 18 & $-3^{* *}$ & 257 & 0 & 0.7 & 0 & 289 & 0 \\
\hline 24 & 23 & $-3^{* *}$ & 22 & $-4^{* * *}$ & 221 & 0 & 1.0 & 0 & 225 & 0 \\
\hline 27 & 45 & $-6^{* *}$ & 40 & $-5^{* *}$ & 250 & 0 & 1.1 & 0 & 241 & 0 \\
\hline 18 & 7 & $-1 * *$ & 1 & 0 & 15 & $-3^{*}$ & 0.1 & 0 & 69 & 0 \\
\hline 15 & 7 & 0 & 2 & 0 & 28 & 0 & 0.2 & 0 & 72 & 0 \\
\hline 16 & 7 & $-1^{* *}$ & 0 & 0 & 13 & $-3 * * *$ & 0 & 0 & 68 & 0 \\
\hline \multicolumn{11}{|c|}{ Garden soils } \\
\hline 6 & 25 & $+1 * *$ & 86 & $-22 * * *$ & 175 & 0 & 0.9 & +0.2 & 181 & -12 \\
\hline 7 & 12 & $-2^{* *}$ & 1 & 0 & 11 & 0 & 0.1 & +0.1 & 31 & 0 \\
\hline 14 & 204 & 0 & 129 & $-42^{* * *}$ & 327 & 0 & 14.5 & 0 & 134 & 0 \\
\hline 26 & 262 & 0 & 111 & $-23 * * *$ & 224 & $+31 * * *$ & 8.5 & -1.3 & 79 & +38 \\
\hline 22 & 157 & 0 & 68 & $-19 * * *$ & 348 & $-37 * * *$ & 4.7 & -0.2 & 229 & 0 \\
\hline 3 & 42 & $-7 *$ & 52 & $-26 * * *$ & 277 & 0 & 1.5 & +0.4 & 248 & +10 \\
\hline 5 & 15 & $-1^{*}$ & 36 & 0 & 289 & $-21 * *$ & 0.5 & 0 & 374 & -31 \\
\hline 21 & 272 & 0 & 167 & $-72^{* * *}$ & 529 & $-28 * *$ & 24.4 & +0.8 & 205 & -37 \\
\hline 23 & 118 & $-8^{*}$ & 65 & $-21 * * *$ & 355 & $-56 * *$ & 9.6 & +0.6 & 197 & -56 \\
\hline 25 & 131 & 0 & 105 & $-34 * * *$ & 368 & 0 & 16.6 & -0.3 & 168 & -11 \\
\hline \multicolumn{11}{|c|}{ Virgin soils } \\
\hline 13 & 7 & 0 & 2 & $+2 * * *$ & 32 & $+6 * * *$ & 0.1 & 0 & 107 & +11 \\
\hline 31 & 8 & 0 & 2 & 0 & 71 & 0 & 0 & 0 & 222 & -36 \\
\hline 32 & 24 & 0 & 2 & 0 & 56 & . 0 & 0.3 & +0.1 & 95 & 0 \\
\hline 2 & 6 & 0 & 1 & $+1 * * *$ & 46 & $+8 * * *$ & 0.1 & 0 & 182 & +12 \\
\hline
\end{tabular}

\section{Discussion}

The three tests studied in the present paper are supposed to give a picture of the phosphorus conditions of the soils. They do that in ways which are essentially different. The acetic acid probably extracts some of the phosphorus bound by calcium, while the nexchangeable $\mathrm{P}_{n}$ represents most of the fractions of inorganic $\mathrm{P}$ bound by iron and aluminium compounds. Acid ammonium fluoride is likely to extract mainly aluminium bound $\mathrm{P}$, but some calcium bound or even iron bound $\mathrm{P}$ may be included. The acetic acid $\mathrm{P}$ and the sorbed $\mathrm{P}$ of the two rapid tests are both taken to show the content of easily available $\mathrm{P}$ in soil. The 
nexchangeable $\mathrm{P}_{n}$ represents the $\mathrm{P}$ resources of the soil, and only in connection with the data indicating the $\mathrm{P}$ concentration of the soil solution, $\mathrm{y}_{0}$, and the phosphate sorption capacity $a$, it may be used to characterize the $\mathrm{P}$ condition of a soil.

It seems that air-drying did not markedly change the fairly poor information of the $\mathrm{P}$ condition of the present soils given by the acetic acid method. The trend appeared to be somewhat different from that reported by JACKson (3). According to his observations air-drying samples of acid soils may markedly increase the dilute acid extractable $\mathrm{P}$, while with limed and highly fertilized soils the dilute acid extractable $\mathrm{P}$ decreased by drying. In the present material only the samples $6,9,3$, and 8 behaved in this way.

The result that air-drying tended to decrease the absorbed $\mathrm{P}$ more often and to a larger extent than the acetic acid $\mathrm{P}$ may be partly explained on the basis of the different period of extraction. The soil is in effective connection with the acid ammonium fluoride solution only for one minute, while the shaking period in acetic acid is one hour. Even the moistening of the dry soil sample takes a far larger part of the time of contact in the former case than in the latter one, and although no equilibrium were reached in the acetic acid suspension, the resorption of the dissolved $\mathrm{P}$ may be marked. On the average, air-drying decreased the acetic acid $\mathrm{P}$ of the present material by 5 per cent, and the corresponding decrease in the values of adsorbed $\mathrm{P}$ is 11 per cent. Yet, it seems that the test for adsorbed $\mathrm{P}$ performed on air-dried samples does not usually give any markedly misleading picture of the conditions in fresh soils.

The same conclusions appears to be valid in regard to TERÄSvUORI's method. The changes caused by air-drying in $y_{0}$ are usually low. Since a change in $x_{0}$ is often connected with a similar change in the indicator of the sorption capacity $\alpha$, the ratio $\mathrm{x}_{\mathrm{o}} / \alpha$ which according to TERÄSVUORI is correlated with the degree of the $\mathrm{P}$ saturation of the soil, does not in the air dry samples markedly differ from the corresponding ratio in the fresh soil.

There are some facts which diminish the importance of the possible difference in the results of phosphorus analyses performed on fresh and air-dried soil samples. First, the soil phosphorus is a dynamic complex. The variation in the forms and solubility of soil $\mathrm{P}$ may be marked even within a growing period, owing to the microbial activity, climatic conditions, effect of the plant roots, etc. Second, it is likely that the sampling errors are usually larger than the errors caused by airdrying of samples.

\section{$S u m m$ ary}

The effect of drying of soil samples at about $20^{\circ} \mathrm{C}$ on the phosphorus test values estimated by the acetic acid method, the method for adsorbed P of BRAY and KURTz (1), and the method of TERÄSvUORI (6) was studied. The material consisted of 32 samples of various kinds of soils.

Air-drying did not cause any change in the acetic acid $\mathrm{P}$ of about one half of the samples and in the adsorbed $\mathrm{P}$ of about one third of the samples. A slight increase in the test values was found for a couple of samples. The tendency to a 
decrease was markedly higher in the values of adsorbed $\mathrm{P}$ than in the values of acetic acid P: an average decrease of 28 per cent in 19 samples was found in the former test while the corresponding value in the latter test was 13 per cent in 13 samples.

No changes in the test values of Teräsvuori occurred in about one half of the samples, and the fairly low changes in the other half of the material were almost evenly distributed between increases and decreases.

No connection between the changes in the test values upon air-drying and the moisture content of the fresh sample, the pH-value, the content of organic carbon, or the contents of iron and aluminium soluble in TAmm's acid oxalate solution could be demonstrated. The changes in the various test values did not usually go in same direction.

The importance of the possible error caused by air-drying is diminished by the sampling errors and by the variation in the soil $\mathrm{P}$ conditions.

\section{REFERENCES}

(1) BrAY, R. H. \& KURTz, L. T. 1945 Determination of total, organic, and available phosphorus in soils. Soil Sci. 59: $39-45$.

(2) Hoffmann, W. \& Steinfatt, K. 1959. Vergleichende Untersuchungen über die Löslichkeit der pflanzenaufnehmbaren Nährstoffe Kali und Phosphorsäure in frischen und lufttrockenen stark humosen und organogenen Böden. Landw. Forsch. 12: $77-87$.

(3) JAckson, M. L. 1958. Soil chemical analysis. Englewood Cliffs, N.J. 498 p.

(4) KAILA, A. 1949. Maan fosforintarpeen määrittämisestä (Summary: On testing soils for phosphorus deficiency) Reports of State Agr. Res. 220.

(5) - - \& RYTI, R. 1951. Observations on factors influencing the results of chemical soil tests. Acta Agr. Scand. 1: $271-281$.

(6) TERÃSvUORI, A. 1954. Uber die Anwendung saurer Extraktionslösungen zur Bestimmung des Phosphordüngerbedarfs des Bodens, nebst theoretischen Erörterungen über den Phosphorzustand des Bodens. Publ. Staatl. Landw. Vesuchswesen in Finnland N:r 141.

(7) WALKLEY, A. 1935. An examination of methods for determining organic carbon and nitrogen in soils. J. Agr. Sci. 25: $598-609$.

SELOSTUS:

TUOREIDEN JA ILMAKUIVIEN MAANÅYTTEIDEN FOSFORITESTIEN TULOKSISTA

Armi KaIla

Yliopiston maanviljelyskemian laitos, Helsinki

Maanäytteiden kuivatus $20^{\circ} \mathrm{C}$ :ssa vaikutti eri testien arvoihin eri tavoin. BrAYn ja Kurzin pikamenetelmän happamaan ammoniumfluoridiin liukeneva fosfori aleni suhteellisesti enemmän ja useammassa tapauksessa kuin etikkahappoon liukeneva fosfori. Muutokset eivät kuitenkaan vaikuta paljon näiden testien antamaan epävarmaan tietoon maan fosforitilanteesta.

TERĀSVUOREN menetelmän tulokset tuoreista ja ilmakuivista näytteistä eivät eronneet olennaisesti.

On syytä otaksua, että maanäytteiden ottoon liittyvät virheet ja maan dynaamisessa tilassa olevan fosforin liukenevuuden muutokset ovat tavallisesti suuremmat kuin näytteiden ilmakuivatuksen aiheuttamat. 